\title{
Seasonal ultraviolet B light availability in European countries and its impact on serum 25-hydroxyvitamin D
}

The major source of vitamin D in humans is the dermal synthesis of cholecalciferol in the presence of ultraviolet B (UVB) radiation ${ }^{(1)}$. Food sources of vitamin D are few; typical mean intakes in populations within the European Union are generally around 3-7.5 $\mu \mathrm{g} / \mathrm{d}^{(2)}$. Recent research has shown that $13 \%$ of European individuals have vitamin D deficiency (serum 25-hydroxyvitamin D [25(OH)D] concentrations $\left.<30 \mathrm{nmol} / \mathrm{L}^{(1)}\right)$ on average in the year ${ }^{(3)}$. The objectives of this work were to assess the availability of UVB $\left(\mathrm{Jm}^{-2}\right)$ across Europe and to compare this UVB data with monthly serum $25(\mathrm{OH}) \mathrm{D}$ concentrations $(\mathrm{nmol} / \mathrm{L})$ in two case-study Northern and midlatitude European countries (Tromsø, Norway $\left[69^{\circ} \mathrm{N}\right]$ and Ireland $\left[51-54^{\circ} \mathrm{N}\right]$, respectively) as exemplars.

UVB availability was modelled for countries across Europe, as previously described and validated ${ }^{(4)}$. The results showed that UVB availability increased with decreasing latitude (from $69^{\circ} \mathrm{N}$ to $35^{\circ} \mathrm{N}$ ) (data not shown). Standardized serum $25(\mathrm{OH}) \mathrm{D}$ concentrations from the National Adult Nutrition Survey in Ireland and from the Tromsø 6 cohort study in Tromsø, Norway were used to generate monthly means and standard deviations. Fig 1 shows the seasonal variation in both the UVB availability (average of 10 year period) and serum $25(\mathrm{OH}) \mathrm{D}$ concentrations for Ireland and Northern Norway over a typical 12 month period. Using a cut-off of $1000 \mathrm{Jm}^{-2}$, below which the capacity for dermal synthesis of vitamin D is insufficient, showed that Ireland and Northern Norway had 5 and 8 months of the year, respectively, where UVB fell under this threshold. Despite this, serum $25(\mathrm{OH}) \mathrm{D}$ concentrations of Norwegian adults is noticeably higher than that of Irish adults during these vitamin D winter periods. The seasonal fluctuations in serum 25 $(\mathrm{OH}) \mathrm{D}$ concentrations was largely absent in Norwegian adults, despite clear variation in UVB availability (Fig 1).
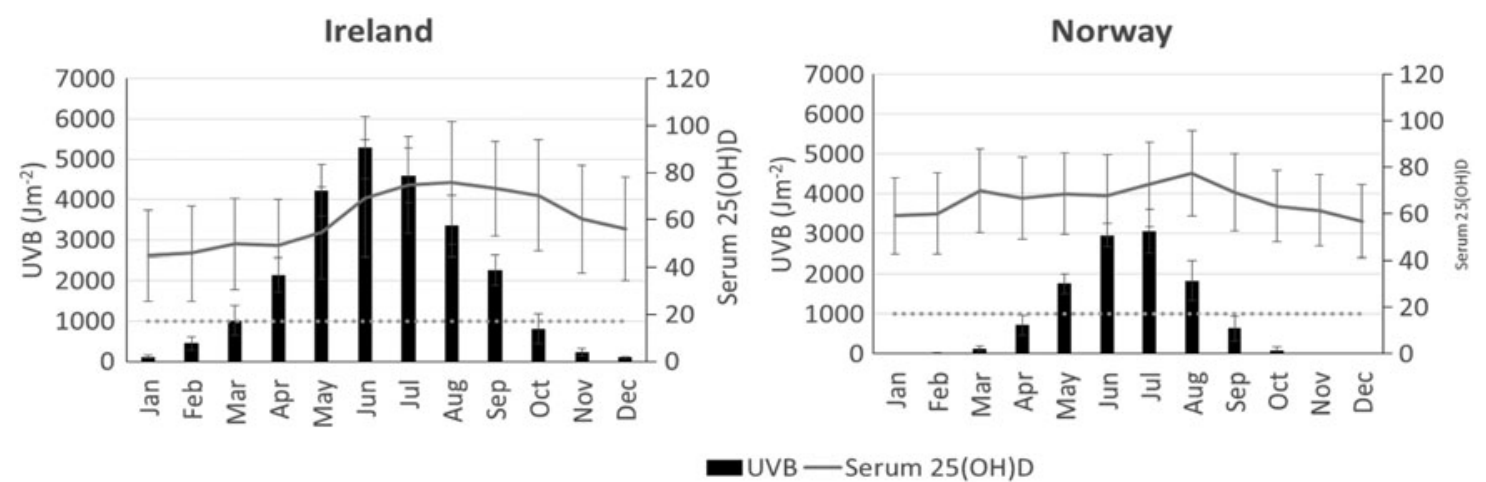

Fig. 1. Modelled UVB availability and measured serum 25(OH)D concentrations ( $n=25-1896 /$ month) over 1 year in Ireland and Northern Norway (monthly means and standard deviations).

The mean daily intake of vitamin D by Irish adults in 2009/10 was $5 \mu \mathrm{g} / \mathrm{d}$ compared to $12 \mu \mathrm{g} / \mathrm{d}$ in Norwegian adults in 2011 . The higher intake in Norway stems from a higher rate of vitamin D supplement usage and greater fish consumption compared to that in Ireland. In conclusion, increasing the vitamin D intake (via food fortification and/or supplement use) can ameliorate the impact of low UVB availability on serum $25(\mathrm{OH}) \mathrm{D}$ status in Europe.

Research supported by funding from the EU (FP7/2007-2013) under grant agreement no. 613977 (ODIN)

1. Institute of Medicine Food and Nutrition Board. Dietary reference intakes for calcium and vitamin D. Washington (DC): The National Academies Press; 2011.

2. Kiely Black. Dietary strategies to maintain adequacy of circulating 25 -hydroxyvitamin D concentrations. Scand J Clin Lab Invest Suppl 2012;243:14-23.

3. Cashman et al. Vitamin D deficiency in Europe: pandemic? Am J Clin Nutr, 2016.

4. Kazantzidis Webb et al. A modeling approach to determine how much UV radiation is available across the UK and Ireland for health risk and benefit studies. Photochem Photobiol Sci, 2015. 